\title{
URODYNAMIC PRACTICE IN NEURO-UROLOGICAL PATIENTS: TECHNIQUES AND CLINICAL VALUE
}

\author{
By H. Madersbacher, M.D. ${ }^{1}$ and P. Dietl, M.D. \\ ${ }^{1}$ Consultant Urologist. Rehabilitationszentrum der AUVA Bad Häring, A-6323 Bad \\ Häring, Tyrol, Austria.
}

Summary. During the last decade a variety of urodynamic techniques have been developed. Despite this there is a tendency to be somewhat inflexible in the application of urodynamics; as soon as the investigator becomes familiar with one method he tends to use it for all his urodynamic evaluations.

A short survey gives information about the most popular urodynamic methods with their combinations, as well as their clinical value for paraplegics. The type and number of urodynamic techniques used at the Rehabilitation Centre Bad Häring during the last 6 years demonstrate that extensive facilities are desirable. This gives the flexibility to choose the proper technique, giving maximal information for the individual patient with minimal costs.

The combination of cystometry with X-ray videography (the simplest form of videourodynamics), is the most frequent method used, whereas the time consuming combined pressure-flow-EMG-X-ray-video-studies are only used for special indications (approximately Io per cent of all our urodynamic studies).

In order to obtain information of clinical value sometimes a compromise is necessary in order to find the method somewhere between what we would like to measure and the disturbance caused to the patient.

Key words: Urodynamic techniques; Evaluation of neuropathic bladder dysfunction; Urodynamic equipment.

\section{Introduction}

THERE IS a tendency to be somewhat inflexible in the application of urodynamics. Often one standard technique, which may be sophisticated and time-consuming, is used and considered to be essential for all patients. Considering the variety of urodynamic techniques available, and the problems of managing bladder dysfunction in paraplegic patients, the investigation should be adopted to the diagnostic needs for practical and economic reasons. The urological key observations for paraplegics are: detrusor function, sphincter function specially related to outflow obstruction, and to what degree secondary structural changes enhance or complicate detruso-sphincter-dysfunction.

\section{Survey of urodynamic techniques and their value}

Cystometry, introduced about roo years ago (Mosso and Pellacani, I 882), is the most popular and most frequently used method. It informs about detrusor contraction, about contractility, and about sensation and conscious control. To differentiate between detrusor contractions from externally exerted pressure, intravesical and intrarectal pressure must be measured simultaneously but reflex rectal contractions in paraplegics can be sometimes 


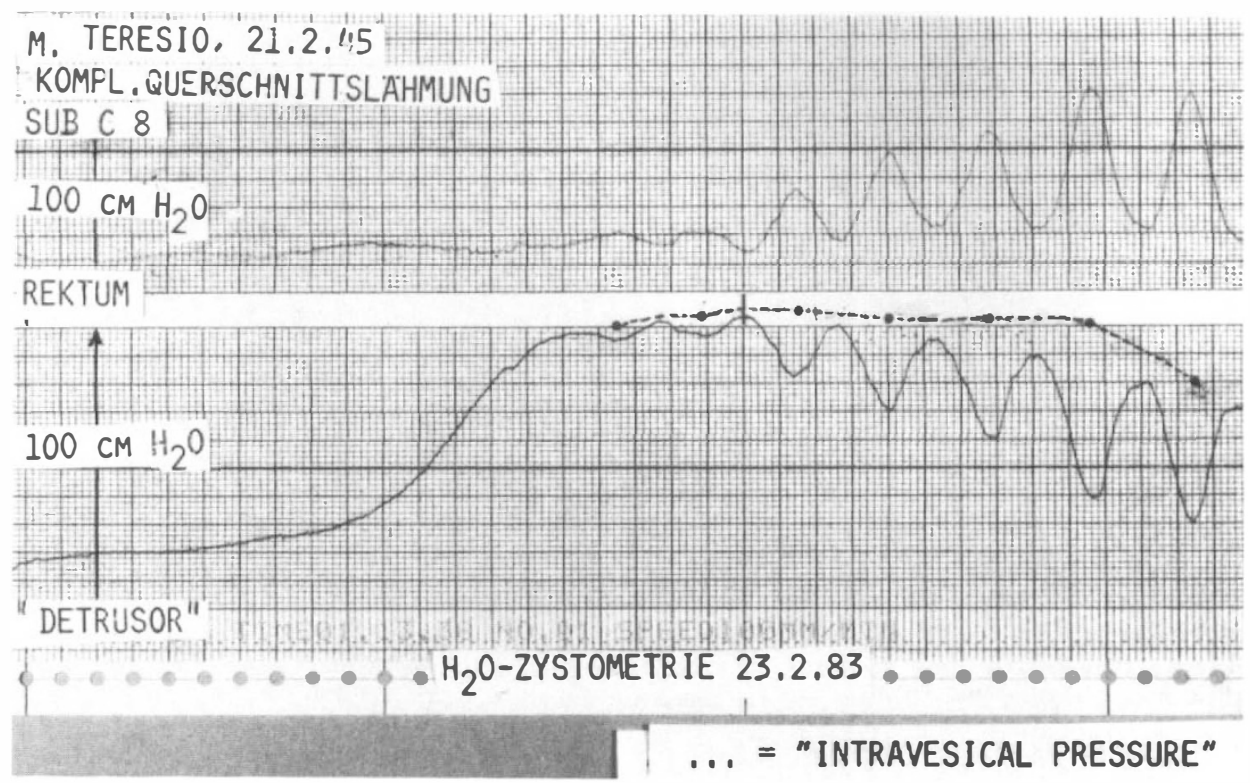

FIG. I

The simple recording of the detrusor pressure (intrinsic bladder pressure), which is the electronically subtracted curve of intravesical minus intrarectal pressure may be misleading especially in paraplegia because of reflex-contractions of the rectum. The lower curve presents a detrusor pressure curve with an undulatory shape on the descending part. The cause of this is not the detrusor but reflex contractions of the rectum as shown in the upper curve representing intrarectal pressure. The dotted line shows the real intravesical curve.

powerful and may therefore influence the subtracted curve so that its interpretation is then misleading (Fig. I).

Thus, if detrusor reflex function has already developed, or if hypercontractility persists, a simple water or gas cystometry (done as a bedside test), is sufficient and takes a few minutes to carry out. However, cystometry, as a single test, gives no direct information about the existence of outflow obstruction but the absence of fluid or gas escape, despite forceful detrusor contractions, is suggestive. Uroflowmetry is a simple screening test to detect abnormal flow patterns in patients with suspected neuropathic bladder disturbance (Madersbacher, 1975). As a single test it is only of limited value for paraplegics in follow-up and therapy control as the flowrates may vary from day to day depending on various factors e.g. spasticity, and micturition may not be assessed in the position these patients normally use for their bladder emptying.

\section{Combined cystometry and uroflowmetry}

Good detrusor contractions together with a poor flow rate indicates outflow obstruction but does not give information about the type or location of the obstruction and therefore is not much more informative than simple cystometry.

In the majority of patients knowledge of detrusor and of sphincter 
function is essential, since detrusor sphincter dyssynergia is of vital importance in the pathophysiology of micturition in patients with reflex and uninhibited bladder (Madersbacher, 1979). The simultaneous evaluation of detrusor and external sphincter function may be obtained by combined cystometry and EMG of the peri-urethral striated musculature (Diokno et al., 1974). With this technique the behaviour of the external sphincter can be evaluated during bladder filling and micturition. The existence, degree and type of external sphincter dyssynergia (Blaivas et al., I98I), can be detected by this method (Fig. 2). However, this method gives no information about the function of the bladder neck or of any secondary, structural complications of bladder and sphincter-dysfunction.

\section{Combined cystometry-X-ray-Videography}

The combination of cystometry with X-ray-videography is an effective method in the evaluation of bladder and bladder outlet function. It allows the evaluation of the detrusor and the determination of the type and location of outflow obstruction. It is also possible to diagnose secondary structural

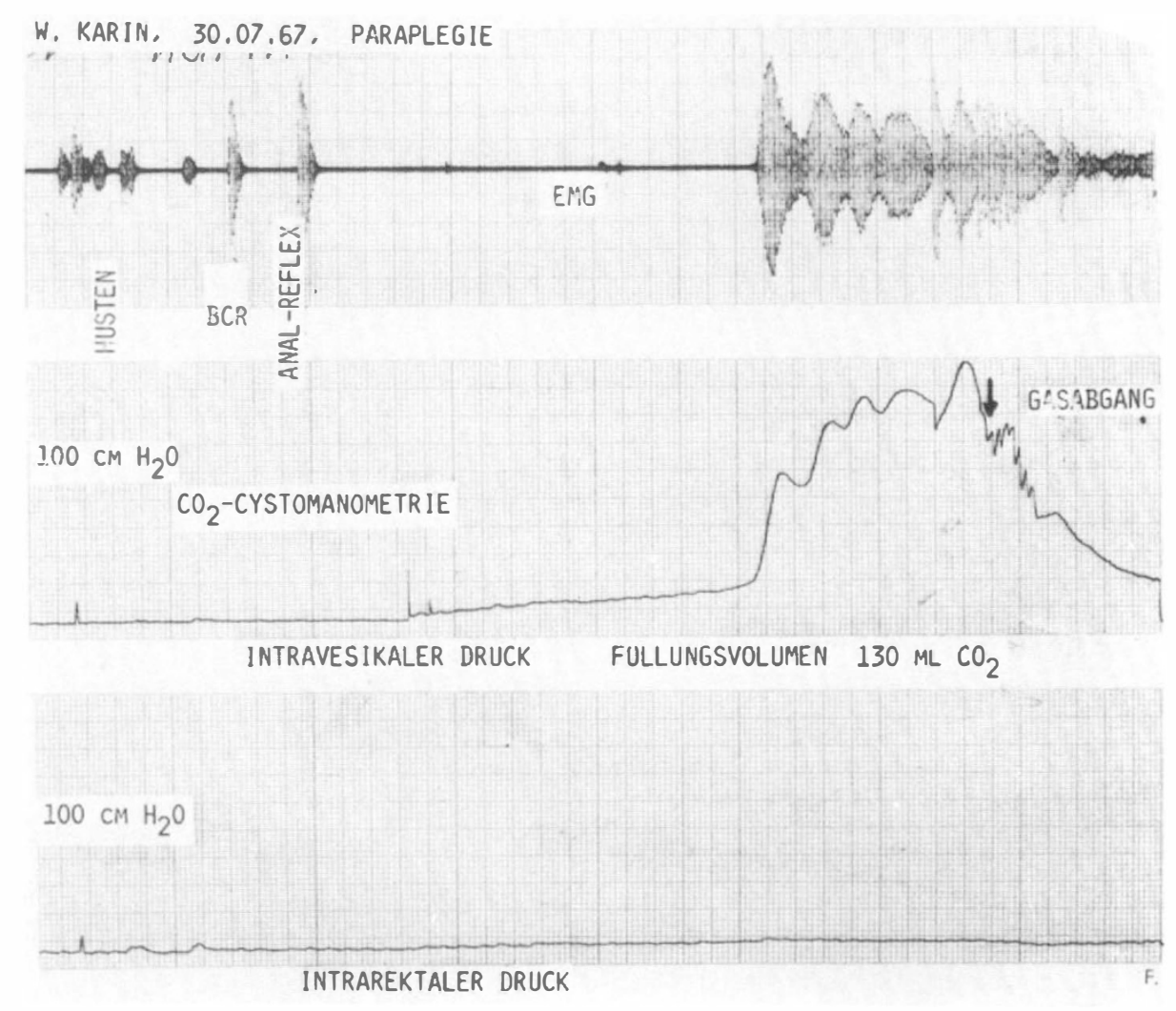

FIG. 2

Combined cystometry-EMG: the increase of EMG activity of the external sphincter together with the onset of detrusor contraction clearly demonstrates detrusor-sphincter ext. dyssynergia; filling medium for the bladder is $\mathrm{CO}_{2}$; for the EMG wire-electrodes are used. 

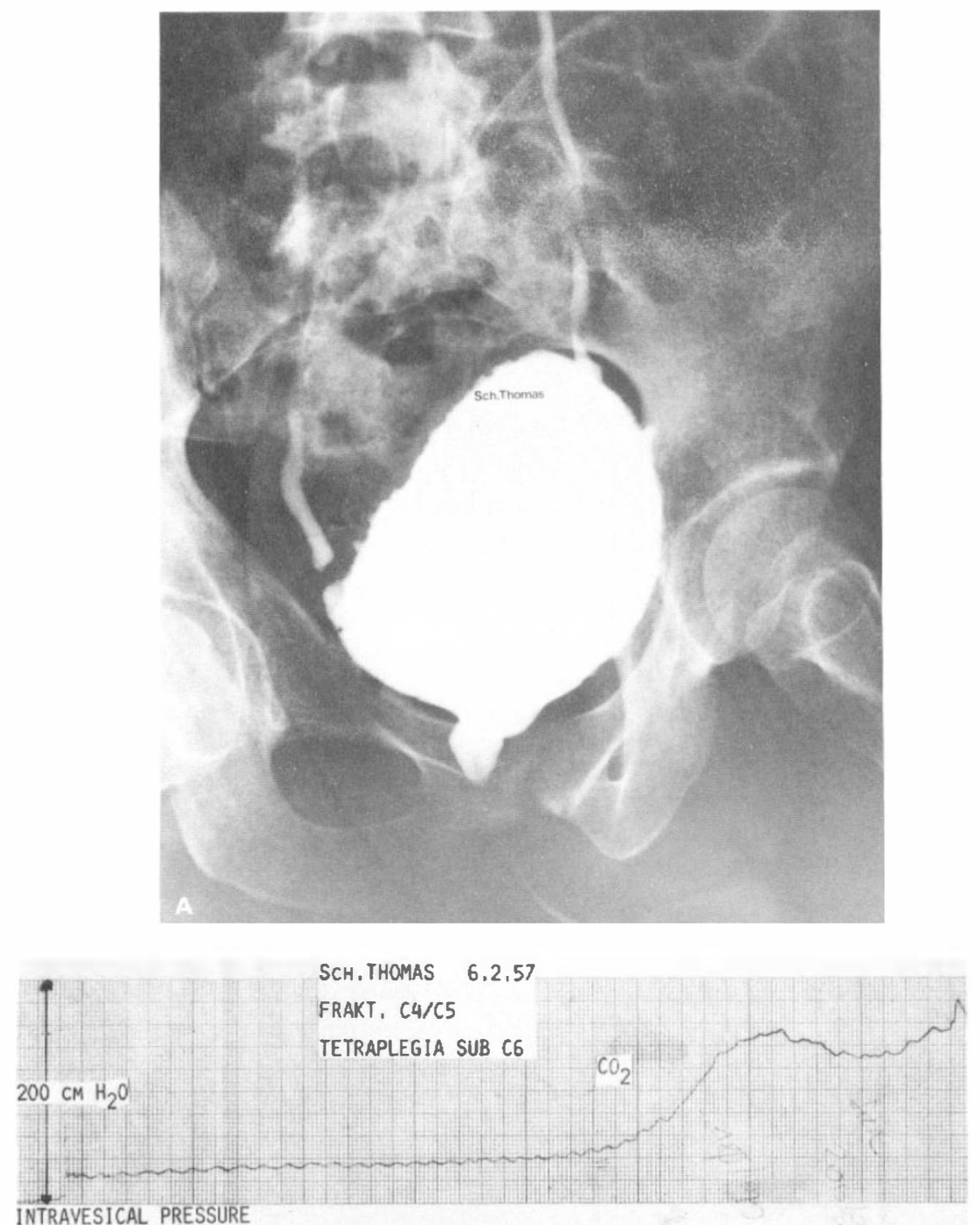

B

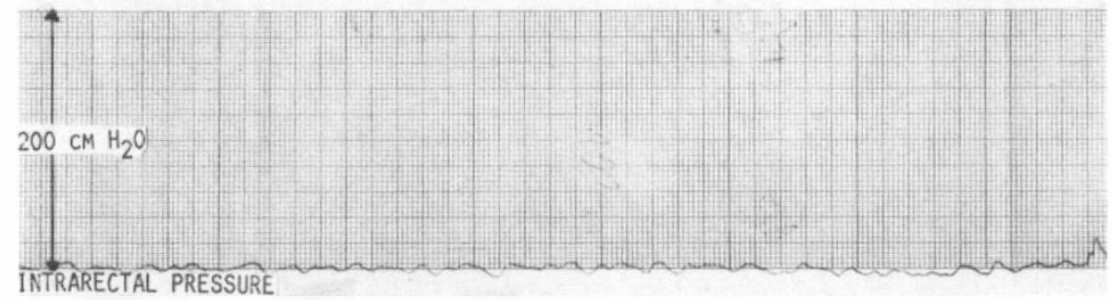

FIG. 3

$\mathrm{A}$ and $\mathrm{B}$; combined cystometry and X-ray videography: narrowing of the posterior urethra at the level of the pelvic floor and amphora-like dilatation of the proximal part indicates external-sphincter-dyssynergia in a tetraplegic; the presence of bilateral reflux and the hypercontractility of the detrusor together with dysreflexia require lowering of outflow resistance by sphincterotomy. 
changes such as trabeculation and reflux (Fig. $3 \mathrm{~A}$ and $\mathrm{B}$ ). It is therefore valuable in the pre-operative evaluation of bladder outflow obstruction and assists in the choice of appropriate surgery (Fig. 4). Videography is the only method which is able to demonstrate function or dysfunction of the bladder neck. For routine evaluation of the detrusor-sphincter-complex we regard combined cystometry-X-ray-videography as the most efficient and economic technique (Rickwood et al., I982).

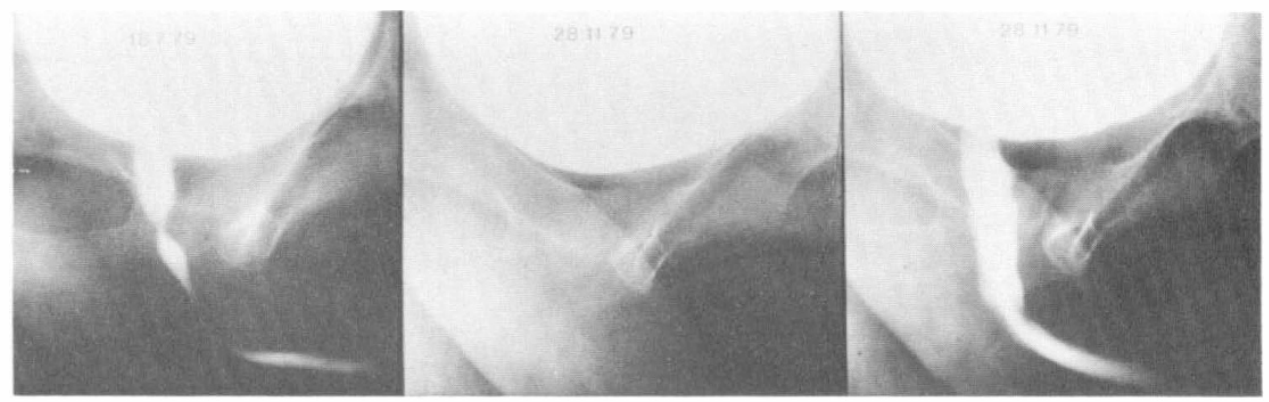

FIG. 4

Video-urodynamics can indicate the presence of outflow obstruction and its precise situation. Moreover with observation of the filling phase and micturition it is possible to predict if the continence/incontinence situation will change post-operatively. On the left is the pre-operative micturition X-ray indicating external sphincter dyssynergia; the bladder neck had remained closed up to $300 \mathrm{cc}$; a distal antero-median sphincterotomy was performed, without interfering with the bladder neck or proximal posterior urethra. No change of the continence situation should therefore occur and the post-operative cystogram (middle) confirms this prediction. Once again the bladder neck remains closed up to $300 \mathrm{cc}$ but during micturition (right) the sphincterotomised part of the distal urethra is widely open.

\section{Combined pressure flow, E.M.G. and X-ray video-study}

If cystometry and videography are combined, with additional simultaneous flow and EMG this technique provides excellent evaluation, localisation and documentation of detrusor and sphincter function, and of secondary structural changes (Cardus et al., 1963; Madersbacher, 1977). It is also useful in the pre-operative evaluation of outflow obstruction. This question may be crucial especially in ambulant patients with incomplete lesions, in whom some conscious control of micturition is still present and must be preserved (Fig. 5A, B and C). From our experience of children with congenital spinal cord lesions this type of investigation is preferable. To minimize artefacts we prefer a suprapubic approach to the bladder for this type of investigation.

Recently we have used a microtip catheter with two pressure transducers and now have a limited experience of simultaneous intravesical and intraurethral pressure recordings, together with $\mathrm{X}$-ray videography during filling and micturition. There is no doubt that this method, irrespective of which technique for intra-urethral pressure recording is used, can give precise and complex information about the underlying pathophysiology (Yalla et al., I975; Rossier, I982) as shown in Figure 6. In contrast to the EMG it allows quantification of sphincter-dyssynergia. Because of the 
G.FRANZ, 7.11 .19 KONTUSION DER HWS TETRAPARESE SUB C7 (15.5.82)

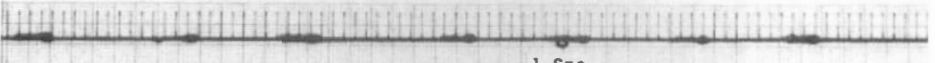
URODYN, U, $15.12,82$

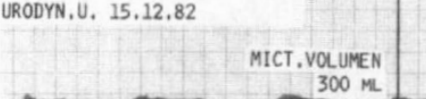
FLOW $1 \mathrm{SEC}$.

EMG (SPHINCT,EXT./PELVIC FLOOR M.)
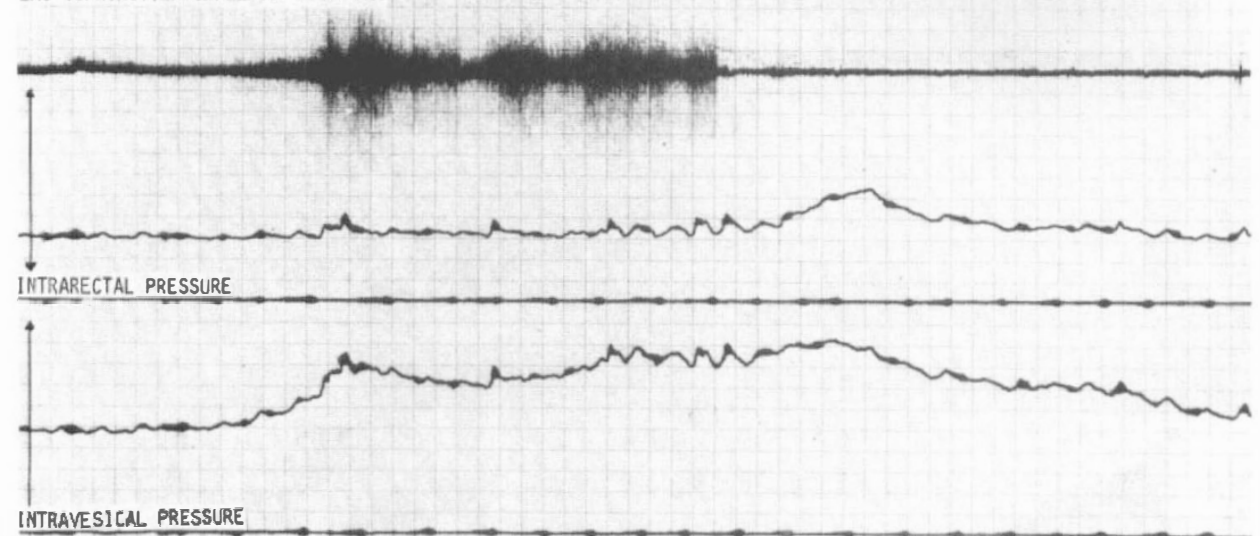

A INTRAVESICAL PRESSURE

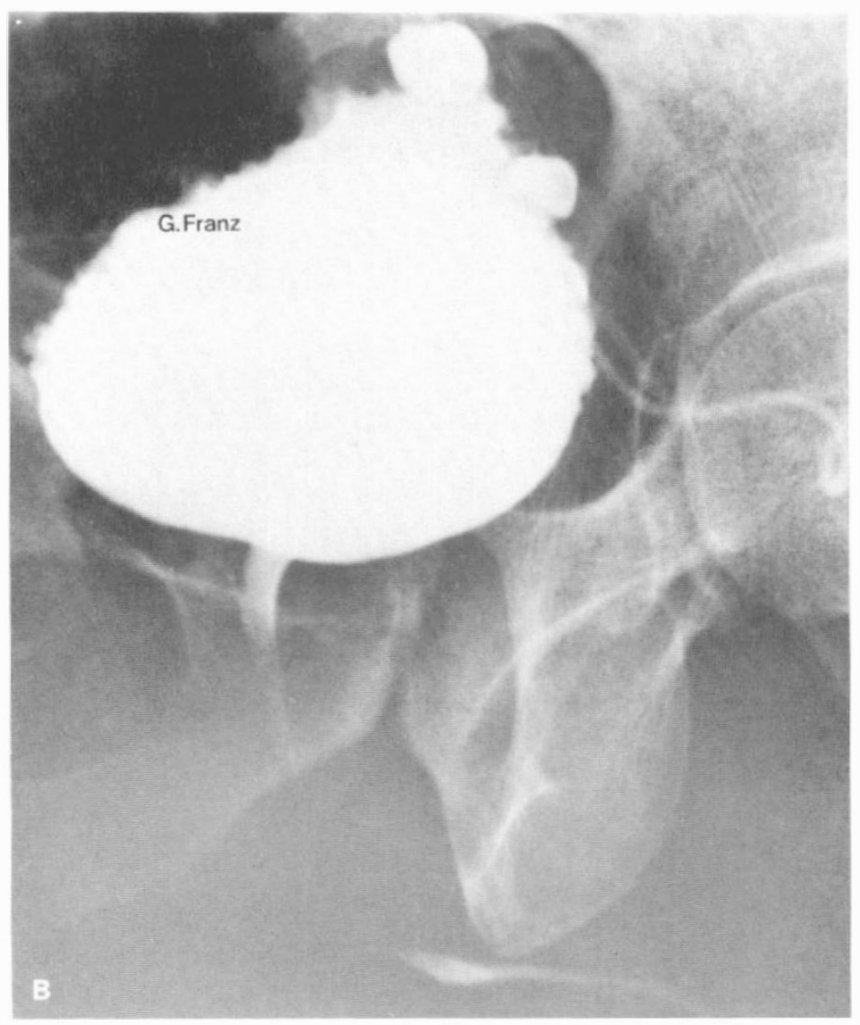




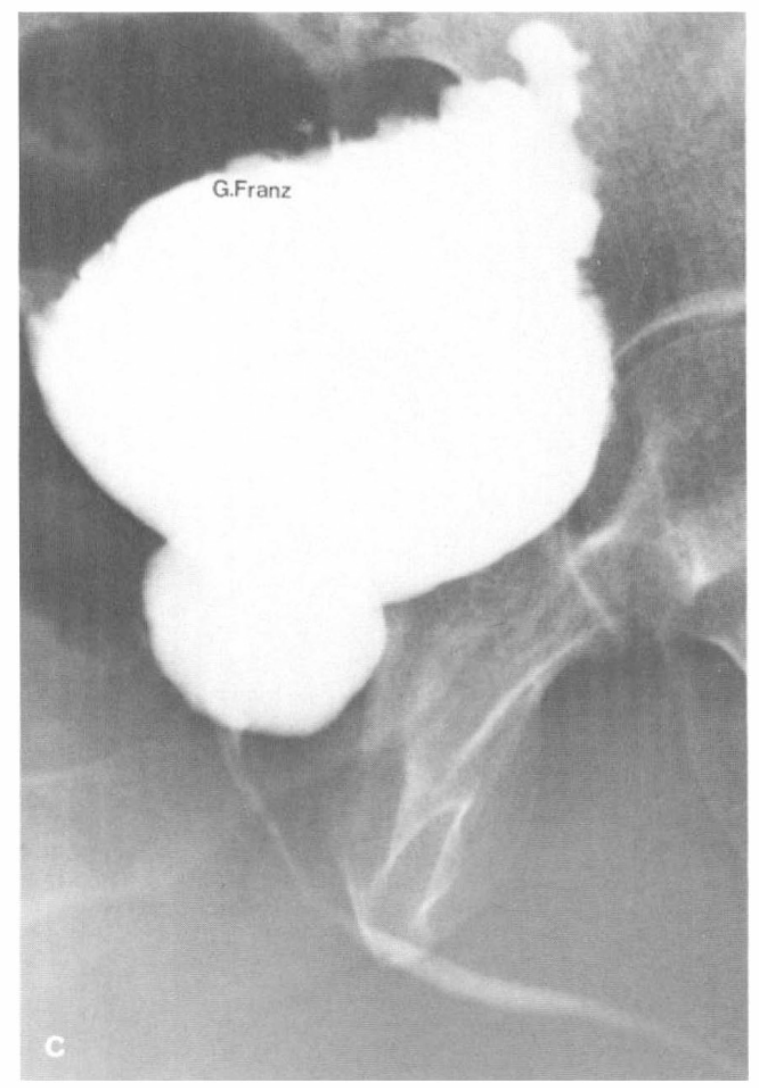

FIG. 5

A, B and C; combined pressure-, flow-, EMG- and X-ray videostudy. A 63-year-old male with tetra-paresis after contusion of the cervical cord: uninhibited bladder, residual urine, ranging up to 50 per cent of bladder capacity, his prostate is enlarged; however, according to a previous $\mathrm{CO}_{2}$-cystometry-EMG, the external sphincter is dyssynergic; this study shows that there is in fact some sphincter-dyssynergia when the detrusor contraction starts; but then the pelvic floor relaxes. Although detrusor pressure remains high and the sphincter is relaxed, flow remains poor indicating prostatic obstruction (Fig. A and B); therefore, only a TUR prostatectomy was performed. The voiding cystogram io days post-operatively (Fig. $5 \mathrm{C}$ ) shows that the prostate is resected and the sphincter area is preserved. There is now little residual urine and the continence situation remained unchanged.

transurethral manipulation and the stiffness of the catheter artefacts must be taken into consideration, especially in spastic patients and in those with preserved sensation.

\section{Methods and Results}

The use of these techniques in the Rehabilitation Centre Bad Häring may indicate the need for the above methods. The vast majority of our patients suffer from spinal cord lesions, mostly of traumatic origin. The urological work-up in the spinal cord injury ward of 50 beds is carried out on a 


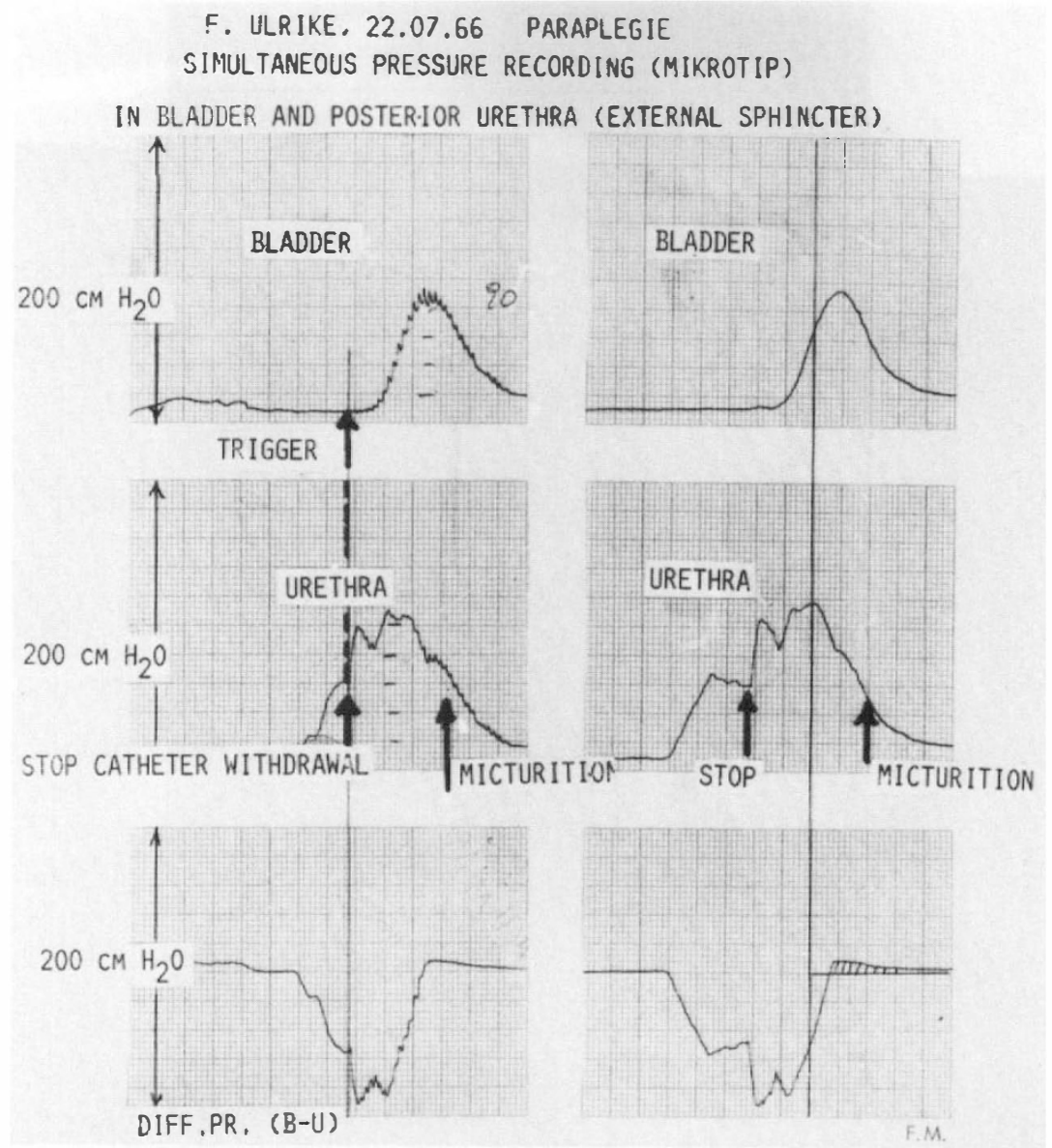

FIG. 6

Simultaneous intravesical and intra-urethral pressure recording during triggered reflexvoiding, one micro-pressure transducer being in the bladder, the other in the posterior urethra at the level of the pelvic floor. The pressure curves clearly show that, prior to the detrusor contraction, a pressure-rise occurs in the sphincter area indicating sphinctercontraction; therefore despite normal detrusor force micturition is delayed and occurs only during the last phase of detrusor contraction.

part-time consultant basis with three half-day sessions a week. The following urodynamic techniques are currently available: uroflowmetry, cystometry (water, gas), cystometry + EMG, cystometry + X-ray videography, combined pressure-flow, EMG-X-ray-videostudies, urethral pressure profiles and simultaneous intravesical and intra-urethral pressure recording.

In a group of 223 patients with recent complete and incomplete spinal cord injury lesions during 6 years (I977-I982), in I47 (66 per cent) a combined cystometry-X-ray-videography was undertaken to evaluate detrusor-sphincter function and was considered to be sufficient; in 36 patients ( 16 per cent) a cystometry only was performed; in 22 (IO per cent) these techniques were not informative enough and had therefore to be completed 
by an extensive combined pressure-flow-EMG-X-ray-videostudy. In I 8 patients $(8$ per cent) with a history and clinical investigation together with IVP, mostly combined with a voiding and post-voiding film (Turner Warwick et al., I 979), there was no further need for urodynamics.

During subsequent admissions in I IO of 293 ( 37 per cent) combined cystometry-X-ray-videography was undertaken and in 2 I per cent a simple cystometry; in only 3 per cent a combined pressure-flow-EMG-X-ray videostudy was necessary either primarily or subsequent to the other urodynamic investigations; in 53 per cent urodynamics were not considered necessary, and in this group are also included those patients who were only controlled by X-ray videography but without pressure recording (Tables I \& II). Patients who had their initial treatment elsewhere, and came up later to our Centre, showed a similar distribution of the different techniques (Tables III \& IV).

The number of combined pressure-flow-EMG and X-ray videostudies has become smaller during the last years due to the increased use of cystometry-X-ray videography and recently cystometry-EMG-studies but probably increased experience is a factor here.

\section{Discussion}

Many different techniques for the urodynamic evaluation of detrusor and sphincter dysfunction in paraplegics are available. It is necessary to

\section{TABLE I}

Patients with recent spinal cord injury (complete and incomplete) initial admission: Number of patients, 223

\begin{tabular}{lrr}
\hline Cystometry only & 36 & $(\mathrm{I} 6 \%)$ \\
Cystometry + subsequent comb. pressure-flow-EMG \& X-ray & 2 & $(\mathrm{I} \%)$ \\
videographic study & $\mathrm{I} 47$ & $(66 \%)$ \\
Cystometry-X-ray-videography average/pat. I.5 & & \\
Cystometry-X-ray-videography + subsequent comb. & 20 & $(9 \%)$ \\
pressure-flow-EMG \& X-ray videographic study & I8 & $(8 \%)$ \\
No urodynamics & $(8 \%)$ \\
\hline
\end{tabular}

\section{TABLE II}

Follow-up after initial treatment at the centre. Number of patients, I 80: Number of admissions, 293

\begin{tabular}{lrr}
\hline Cystometry only & $2 \mathrm{I}$ & $(7 \%)$ \\
Cystometry with subsequent combined pressure-flow-EMG- & 2 & $(\mathbf{I} \%)$ \\
X-ray videographic study & I 10 & $(37 \%)$ \\
$\begin{array}{l}\text { Comb. cystometry-X-ray-videography } \\
\text { Comb. cystometry-videography with subsequent combined } \\
\text { pressure-flow-EMG-X-ray videographic study }\end{array}$ & 3 & $(\mathbf{1} \%)$ \\
$\begin{array}{l}\text { X-ray videographic study (primary) } \\
\text { No urodynamics }\end{array}$ & 2 & $(\mathbf{1} \%)$ \\
\hline
\end{tabular}


TABLE III

Follow-up after initial treatment elsewhere. Initial admission

\begin{tabular}{|c|c|}
\hline \multirow{2}{*}{$\begin{array}{l}\text { Cystometry only } \\
\text { Cystometry \& subsequent combined pressure-flow-EMG-X-ray } \\
\text { videographic study }\end{array}$} & $\left(6_{0}^{0}\right)$ \\
\hline & $\mathbf{I} \quad\left(\mathbf{I}_{0}{ }_{0}\right)$ \\
\hline Cystometry + X-ray videography & $5 \mathrm{I}\left(46.0^{\circ}{ }_{0}^{\prime}\right)$ \\
\hline $\begin{array}{l}\text { ography + subsequent pressure-flow- } \\
\text { ohic study }\end{array}$ & $\left(5 \cdot 0^{0}{ }_{0}\right)$ \\
\hline Combined pressure-flow-EMG-X-ray videographic study only & $\left(3 \cdot 0^{0}{ }_{0}^{0}\right)$ \\
\hline $\begin{array}{l}\text { X-ray-videography + subsequent combined pressure-flow-X-ray- } \\
\text { videographic study }\end{array}$ & \\
\hline No urodynamics & \\
\hline
\end{tabular}

TABLE IV

Follow-up after initial treatment elsewhere, subsequent admissions Number of admissions 255: Number of patients, 142

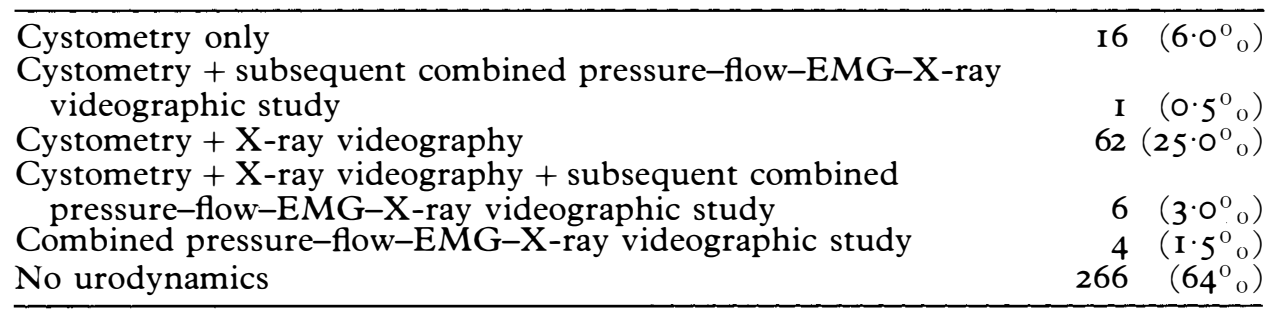

determine, from an exact neuro-urological history and the clinical findings, the need for a minimal or maximal study. For follow-up purposes only one or two urodynamic parameters may be of clinical importance, whereas the evaluation of bladder outflow obstruction in an elderly man with incomplete spinal cord lesion may require an extensive urodynamic investigation. The individual voiding habits and the patient's mobility must also be taken into consideration when making the decision which technique should be applied. Urodynamic studies should be performed either personally by the physician or by a well-trained and experienced technician.

With paraplegics it is essential to clarify bladder and sphincter function during the first stay at the Centre. Our figures show that in only I 6 per cent was cystometry with simultaneous recording of intravesical and intrarectal pressure considered sufficient. The information is of the greatest value when the urologist personally performs these investigations but storage of the X-ray information on video is an alternative.

With decreasing neuropathology, more subtle investigations are necessary to evaluate and classify disorders of micturition and combined pressureflow-EMG-X-ray video studies are sometimes essential.

EMG-evaluation of the peri-urethral striated musculature of the external urethral and anal sphincter (in combination with cystometry), gives the additional information about sphincter function. EMG measurements tend to be subjective and also lack accuracy in electrode placements and are sometimes difficult to interpret due to characteristics of individual recorders. 
These problems become less significant with increasing severity of neuropathology, so that while with incomplete lesions a random-EMG of the pelvic floor is sufficient to document the activity of the external sphincter, in incomplete lesions of any aetiology a separate evaluation of the periurethral striated EMG and anal sphincter EMG is advisable (Vereecken and Verduyn, I970; Madersbacher, I977; Perkash, I980).

Uroflowometry and pressure profiles (Sunder et al., I978; Clarke and Thomas, I98I), as single investigations are useful to understand the underlying pathophysiology but are of limited diagnostic clinical value for paraplegics. However, combined with other techniques they give additional information. Flow pattern and flow values document the effect of detrusorsphincter-dysfunction on micturition and intra-urethral pressure values provide quantitative information on sphincter dyssynergia (Rossier et al., I979).

When discussing the urodynamic observations the possibility of artefacts must be taken into consideration, artefacts due to instrumentation, due to examining the patient in a position to which he is not adjusted or, lastly, due to psychological embarrassment.

A compromise between the number of parameters considered to be useful and the patient's comfort may give the most valuable clinical results.

We conclude that for the evaluation of neurogenic bladder dysfunction extensive equipment is of great advantage. Not all need be applied in every patient but it provides the opportunity to be flexible and so adapt the technique to the diagnostic needs of the individual patient.

\section{RÉSUMÉ}

Pendant les derniéres Io années il y avait un rapid développement des méthodes de mesure urodynamiques et en même temps aussi une certaine inflexibilité dans leur usage. On s'habitue bientot aux certaines méthodes de mesure et donc les emploie routinièrement comme examen urodynamique. Dans un petit sommaire les méthodes de mesure les plus utilisées et leures combinations sont présentées respectivement et leur expréssion clinique discutée tout d'abord. Au moyen des examens faits dans le centre de réhabilitation de Bad Häring pendant les dernières 6 années il est montré, qu'un grand nombre d'instruments est nécessaire pour arriver à une diagnostic. Cet équippement urodynamique est pourtant principalement utilisé pour pouvoir choisir la plus opportune méthode en consideration de l'expression clinique et des dépenses.

La combination de cystomanometrie et videomictiocystourethrographie ainsi que de cystomanometrie et éléctromyographie du sphincter externe sont les méthodes plus fréquemment utilisées par nous à présent, tandis que la 'grande urodynamique' avec enregistrement simultané de la pression, flow, éléctromyographie et radiographie soit emploiée seulement dans certaines indications, pas finalement à cause tu temps. Ainsi la 'grande urodynamique' ne constitue que $\mathrm{IO}^{\circ}$. de touts les examens urodynamiques. L'instrumentation, une position défavorable ainsi que des facteurs psychogènes peuvent causer des fautes, auxquelles on doit faire attention particulièrement chez des patients avec de lésions incomplettes et qualités sensibles maintenues.

\section{ZUSAMMENFASSUNG}

Die letzten Io Jahre brachten eine rasche Entwicklung verschiedener urodynamischer Meßmethoden, gleichzeitig aber auch eine gewisse Inflexibilität in der Anwendung derselben. Der Untersucher gewöhnt sich rasch an bestimmte Meßmethoden und wendet sie dannverständlicherweise-routinemäßig zur urodynamischen Abklärung an. In einer kurzen Ubersicht werden zunächst die gebräuchlichsten Untersuchungsmethoden bzw. ihre Kombinationen dargestellt und ihre klinische Aussagekraft diskutiert. An Hand der im 
Rehabilitationszentrum Bad Häring durchgeführten urodynamischen Untersuchungen der letzten 6 Jahre wird gezeigt, daß zur Abklärung von neurogenen Blasenentleerungsstörungen ein umfangreiches Instrumentarium notwendig ist. Diese urodynamische Ausrüstung wird jedoch in erster Linie dazu benötigt, um beim einzelnen Patienten die für die vorliegende Fragestellung zweckmäßigste Methode-zweckmäßig im Hinblick auf Aussagekraft und Aufwand-auswählen zu können.

Die Kombination von Cystomanometrie und Videomiktionscystourethrographie sowie von Cystomanometrie und EMG des Beckenbodens bzw. des externen Sphinkters sind die von uns zur Zeit am häufigsten angewandten Methoden, während die 'große Urodynamik' mit simultaner Druck-, Fluß-, EMG- und Röntgenaufzeichnung nicht zuletzt aus Zeitgründen nur bei bestimmten Indikationen angewandt wird und deshalb nur ca. $10 \%$ aller urodynamischen Untersuchungen ausmacht. Instrumentation, eine für den Patienten ungewohnte Lagerung sowie psychogene Faktoren können zu Artefakten führen, auf die besonders bei Patienten mit inkompletten Läsionen und erhaltenen sensiblen Qualitäten zu achten ist.

Mitunter erfordert die Zahl der als wünschenswert erachteten urodynamischen Parameter und die damit für den Patienten verbundenen Unannehmlichkeiten mit den daraus möglicherweise resultierenden Artefakten einen Kompromiß um ein aussagekräftiges Ergebnis zu erhalten.

\section{REFERENCES}

Blaivas, J. G., Sinha, H. P., Zayed, A. A. \& Labib, K. B. (i98I). Detrusor-external sphincter-dyssynergia: a detailed electromyographic study. F. Urol., I25, 545-548.

Cardus, D., Queseda, E. M. \& Scott, F. B. (I963). Studies on the dynamics of the bladder. F. Urol., 90, 425-433.

Clarke, S. J. \& Thomas D. G. (I98I). Characteristics of the urethral pressure profil in flaccid male paraplegics. Brit. F. Urol., 53, I 57-I6I.

Diokno, A. C., Koff, St. A. \& Bender (I974). Periurethral striated muscle activity in neurogenic bladder dysfunction. F. Urol., I1 2, 743-749.

Madersbacher, H. (1975). Urinary flow and flow pattern in paraplegics. Paraplegia, 13, 95-IOO.

MADERSBACHER, H. (1977). The neuropathic urethra: urethrogram and pathophysiologic aspects. Eur. Urol., 3, $32 \mathrm{I}-332$.

MADERSBACHER, H. (I 977). Das Elektromyogramm des Beckenbodens im Rahmen kombinierter urodynamischer Untersuchungen. Zschr. Urol. 70, 557-583.

Madersbacher, H. (I 977). Combined pressure, flow, EMG and X-ray studies for the evaluation of neurogenic bladder disturbance: technique. Urol. int. 32, I76-1983.

Madersbacher, H. (I979). Detrusor-Sphinkter-Dyssynergie. Akt. Urol., Io, I09-I I 7.

Mosso, A. \& Pellacani, P. (I 882). Sur les fonctions de la vessie. Arch. Ital. Biol., I, 97-I35.

Perkash, J. (I980). Urodynamic evaluation: periurethral striated EMG versus perianal striated EMG. Paraplegia, 18, 275-280.

Rickwood, A. M. K., Thomas, D. G., Philp, N. H. \& Spicer, R. D. (I982). Assessment of congenital neurovesical dysfunction by combined urodynamic and radiological studies. Brit. F. Urol., 54, 51 2-5 I 8.

Rossier, A. B., Fam, B. A., Dibenedetto, M. \& Sarkarati, M. (i979). Urodynamics in spinal shock patients. F. Urol., I 22, 783-787.

Rossier, A. B., Fam, B. A., Lee, I. Y. \& Sarkarati, M. (1983). Observations on the behavior of the vesicourethral complex during detrusor activity in spinal cord injury patients. In Proceedings and foint Meeting, International Continence Society and Urodynamics Society, Aachen 1983, p. I 17, Editors: W. Schäfer, J. Hannappel and W. Lutzeyer, Aachen.

Sunder, G. S., Parsons, K. F. \& Gibbon N. O. K. (1978). Outflow obstruction in neuropathic bladder dysfunction: the neuropathic urethra. Brit. F. Urol., 50, 190-199.

Turner-Warwick, R. T., Whiteside, C. G. \& Milroy, E. G. (I979). The intravenous urodynamogram. Brit. F. Urol., 5I, I 5-I 8.

VEREECKEN, R. L. \& VERDUYN, H. (I970). The electrical activity of the paraurethral and perineal muscles in normal and pathological conditions. Brit. F. Urol., 42, 457463.

Yalla, S., Rossier, A. B. \& FaM, B. (1975). Synchronous cystosphincterometry in patients with spinal cord injury. Urology, 6, 777-788. 